Teacher Education and the New Biology

\author{
Michael J. Reiss \\ Institute of Education \\ University of London \\ 20 Bedford Way \\ London WC1H 0AL \\ UK
}

m.reiss@ioe.ac.uk 


\title{
Teacher Education and the New Biology
}

\begin{abstract}
Recent years have seen a growth not only in biological knowledge but also, and more significantly for teacher education, in the types of knowledge manifested in biology. No longer, therefore, is it adequate for teachers to retain a Mertonian or a Popperian conception of science. Today's teachers of science need also to be able to help their students discuss bioethics and the societal implications of biology, even when these are controversial and contested. Moreover, practical work can no longer be confined to 'pure', 'safe' and 'confined' activities. These are increasingly rejected by students, validly, as boring or irrelevant. Instead, we need to help student undertake a range of activities that help them to develop criticality and the potential for action. While some may see this as an attack on science, I would argue that this attitude is akin to those who once held that religious education (in countries that permit it) should confine itself to 'the faith'.
\end{abstract}




\section{Teacher Education and the New Biology}

\section{Introduction}

I want to begin by describing a view of science education that I believe is still prevalent but is outdated. An intentionally rather simple view will be presented, not because I believe that my case relies on a caricature against which to stand, but because something of a caricature will help point the way I want to argue. Having produced this prevalent, but I argue outdated, view of science education, I first critique it, secondly suggest how we can have a richer view of science and of science education, particularly biology education, and thirdly consider how teacher education might respond.

The prevalent but outdated view of science education goes as follows:

Science is a wonderful way of understanding the world. The last few hundred years have seen a fantastic growth in scientific knowledge and this has allowed new technologies to be developed. These new technologies have enabled people to live longer and to control their lives to a greater extent (through the widespread availability of such things as transport, lighting and heating). The job of science education is to introduce young people to the fundamentals of scientific knowledge so that if they go on to study science after school they will have the necessary basics for further knowledge and understanding and if they do not so that that they will know enough to understand the various scientific 
issues that affect their lives and over which they have some choice, such as whether they should vaccinate their children, avoid excessive use of mobile phones and generate fewer carbon dioxide emissions.

\section{What, for today's biology educator, is wrong with this vision of science education?}

What is wrong with this vision of science education is not so much what it says - I would disagree with almost none of its assertions taken in isolation - but what it does not say. In contradistinction, the following points can be asserted:

- Science teaching needs to acknowledge the extent to which scientists do not simply discover scientific truths.

- Biology teaching is generally better introduced through contexts than through fundamentals.

- Today's biology raises a wide range of ethical issues.

- Biology teaching sometimes needs to result in more than understanding - it should develop the potential for action.

\section{Science teaching needs to acknowledge the extent to which scientists do not simply discover scientific truths}

While historians tell us that what scientists study changes over time, there are reasonable consistencies: 
- Science is concerned with the natural world and with certain elements of the manufactured world - so that, for example, the laws of gravity apply as much to artificial satellites as they do to planets and stars.

- Science is principally concerned with how things are rather than with how they should be. So there is a science of gunpowder and in vitro fertilisation without science on its own telling us whether warfare and test-tube births are good or bad.

However, there is more controversy about precisely how science is done and about the extent to which scientific knowledge exists independently of those who produce it (e.g. Reiss, 2005). A useful point to start is with the views of Robert Merton and Karl Popper.

Robert Merton characterised science as open-minded, universalist, disinterested and communal (Merton, 1973). For Merton, science is a group activity: even though certain scientists work on their own, all scientists contribute to a single body of knowledge accepted by the community of scientists. There are certain parallels here with art, literature and music. After all, artists often exist in movements so that, for example, communities of artists made up the fauvists, the impressionists, the preRaphaelites and the surrealists. But while it makes no sense to try to combine the paintings of the painters within any of these movements, science is largely about combining the contributions of many different scientists to produce an overall coherent model of one aspect of reality. In this sense, science is disinterested; in this sense it is (or should be) impersonal. 
Of course, individual scientists are passionate about their work and often slow to accept that their cherished ideas are wrong. But science itself is not persuaded by such partiality. Time shows which of two or more alternative scientific theories is nearer the truth. For this reason, while scientists need to retain 'open mindedness', always being prepared to change their views in the light of new evidence or better explanatory theories, science itself advances over time. As a result, while some scientific knowledge ('frontier science') is contentious, much scientific knowledge can confidently be relied on: it is relatively certain. We do know more about genetics now than we did 30 years ago and the geneticists of 30 years ago knew more than the geneticists of 60 years ago, and so on.

Karl Popper emphasised the falsifiability of scientific theories (Popper, 1934/1972). Unless you can realistically imagine collecting data that would allow you to refute a theory, the theory isn't scientific. The same applies to scientific hypotheses. So the hypothesis 'All swans are white' is scientific because we can imagine finding a bird that is manifestly a swan (in terms of its appearance and behaviour) but is not white. Indeed this is precisely what happened when early white explorers returned from Australia with tales of black swans. The criterion 'whiteness' was soon dropped from the definition of 'swans'.

Popper's ideas easily give rise to a view of science in which knowledge steadily accumulates over time as new theories are proposed and new data collected to discriminate between conflicting theories. Much school experimentation in science is Popperian in essence: we note that the $\mathrm{pH}$ of the stomach is very different from that of the ileum and hypothesise that enzymes found in the stomach will differ in their 
optimal pHs compared with enzymes found in the ileum. We test this by experimentally determining the optimal $\mathrm{pHs}$ of pepsin and a lipase and find that our hypothesis is confirmed. Until some new evidence causes it to be falsified, we accept it.

There is much of value in the work of Thomas Merton and Karl Popper but most academics who work in the history, philosophy or sociology of science would argue that there is more to the nature of science. Thomas Kuhn made a number of seminal contributions but he is most remembered nowadays by his argument that while the Popperian account of science holds well during periods of normal science when a single paradigm holds sway, such as the Ptolemaic model of the structure of the solar system (in which the Earth is at the centre) or the Newtonian understanding of motion and gravity, it breaks down when a scientific crisis occurs (Kuhn, 1970). At the time of such a crisis, a scientific revolution happens during which a new paradigm, such as the Copernican model of the structure of the solar system or Einstein's theory of relativity, begins to replace the previously accepted paradigm. The central point is that the change of allegiance from scientists believing in one paradigm to their believing in another cannot, Kuhn argues, be fully explained by the Popperian account of falsifiability.

Kuhn likens the switch from one paradigm to another to a gestalt switch (when we suddenly see something in a new way) or even a religious conversion. As Alan Chalmers puts it: 
There will be no purely logical argument that demonstrates the superiority of one paradigm over another and that thereby compels a rational scientist to make the change. One reason why no such demonstration is possible is the fact that a variety of factors are involved in a scientist's judgment of the merits of a scientific theory. An individual scientist's decision will depend on the priority he or she gives to the various factors. The factors will include such things as simplicity, the connection with some pressing social need, the ability to solve some specified kind of problem, and so on. Thus one scientist might be attracted to the Copernican theory because of the simplicity of certain mathematical features of it. Another might be attracted to it because in it there is the possibility of calendar reform. A third might have been deterred from adopting the Copernican theory because of an involvement with terrestrial mechanics and an awareness of the problems that the Copernican theory posed for it.

(Chalmers, 1999, pp. 115-16)

Kuhn also argued that scientific knowledge is validated by its acceptance in a community of scientists. Often scientists change their views as new evidence persuades them that a previously held theory is wrong. But sometimes they cling obstinately to cherished theories. In such cases, if these scientists are powerful (e.g. by controlling which papers get published in the most prestigious journals), scientific progress may be impeded - until the scientists in question retire or die.

Kuhn's views about the way in which scientists work helped give rise to a great increase in work in this area. Some of this was empirical, so that ethnographic studies were undertaken on scientists in laboratories and elsewhere to see what they actually 
did; some of it was historical; some of it conceptual. A particularly valuable contribution was provided by Lakatos (1978). Lakatos argued that scientists work within research programmes. A research programme consists of a set of core beliefs surrounded by layers of less central beliefs. Scientists are willing to accept changes to these more peripheral beliefs so long as the core beliefs can be defended. So, in biology, we might see in contemporary genetics a core belief in the notion that development proceeds via a set of interactions between the actions of genes and the influences of the environment. At one point, it was thought that the passage from DNA to RNA was unidirectional. Now we know (reverse transcriptase, etc.) that this is not always the case. The core belief (that development proceeds via a set of interactions between the actions of genes and the influences of the environment) remains unchanged but the less central belief (that the passage from DNA to RNA is unidirectional) is abandoned.

Lakatos' distinction between core and peripheral beliefs can, I would argue, be useful in understanding how curricula, including school science curricula, change over time. When I started studying science at school in England in the 1960s the key components of the curriculum were practical work (whether by pupils or demonstrations by teachers) and a body of knowledge and understanding in biology, chemistry and physics. There have been changes over the last 40 years, notably:

- New content (earth sciences, astronomy, some contemporary aspects of biology, chemistry and physics)

- Less emphasis on discovery learning in practical work

- More applied science

- More treatment of the social and ethical aspects of science. 
However, these feel like changes at the periphery. It would not, I feel, take long for a good science teacher of 40 years ago to be a good science teacher today. Nor would the science lessons of yesteryear seem incomprehensible to bright pupils of today.

My vision of school biology, and the teacher education that is needed to prepare teachers to teach it, still has at its core teaching about life. However, I would like to argue for the following shifts in emphasis:

- A great use of contexts for the introduction of biological concepts

- A great emphasis on ethical issues

- A deeper understanding of what it is to be human

- Education for action as well as for knowledge and understanding.

Biology teaching is generally better introduced through contexts than through

\section{fundamentals}

Much of school science has the reputation of being difficult, dull, out-of-touch with students' aspirations and irrelevant to society as a whole (Osborne et al., 2003). Specifications have traditionally been constructed from a scientist's viewpoint with the concepts being developed in a pattern that is seen to be sensible by a scientist. So, for example, courses for 16-19 year-olds might start with biochemistry and cell biology and go onto such topics as physiology, genetics, ecology and evolution. But many students see things differently and want teachers to show them why the concept is important. One possibility is to make the context - or storyline - the driving force. 
To a certain extent, the case study / storyline approach is already used by some authors and within some advanced level biology specifications, particularly within certain optional modules (e.g. 'Applications of genetics' and 'Food technology'). However, this approach, of learning through contexts, has been taken much further in the Salters-Nuffield Advanced Biology (SNAB) project that I direct (Reiss, in press). Salters-Nuffield Advanced Biology is a new advanced level biology course for 16-19 year-olds. It is being launched in England and Wales from September 2005; from September 2002 it has been piloted with around 4000 students. Salters-Nuffield Advanced Biology aims to produce a coherent course that will enthuse students and teachers / lecturers by portraying an up-to-date indication of what it is like to use contemporary biology in research, in industry and in everyday life.

Throughout the course, biological principles are studied in the context of real life applications of biology, thus making the content more relevant to students. Having decided on the outline structure of the course, namely five topics at AS and four at A2 for the pilot (subsequently modified to four topics at AS and four at A2 for the roll out version to start in September 2005), the contexts to be included were considered. This process was informed by the many discussions with biologists and advanced level biology teachers / lecturers. The contexts needed to be topical, of interest to the students, but also enduring. For this reason we were reluctant to have too much on recent or (then) currently newsworthy 'crises' in biology, such as BSE (bovine spongiform encephalopathy), the MMR (measles, mumps, rubella) vaccine or footand-mouth disease, for fear that these might date quickly. On the other hand, contexts like global climate change, genetic engineering and cystic fibrosis are likely to be 
around for many years to come. Ten potential contexts were selected and presented at the UK's Association for Science Education Annual Meeting in January 2001. The comments received were positive and also helped us decide on the best order for the topics.

We have attempted throughout the course to make it as likely as possible that students engage with the issues, examine them critically and are able to develop their own opinions, substantiated by evidence. For instance, in topic 4 we use the evidence concerning global climate change as a way of allowing us to introduce the issue of what constitutes a valid scientific hypothesis and why. This should help students appreciate that there can be alternative explanations for scientific observations. In this topic we don't assume or insist that current climate change is caused by humans. We first examine the evidence that the climate really is changing; we then examine the evidence that this change is driven by human actions rather than being natural. For much the same reason we end Topic 4 with an analysis of the way in which different websites present data on climate change to illustrate the point that scientific conclusions about controversial issues can sometimes depend on who is reaching the conclusions.

A number of reasons can be given for which teaching in context makes sense. For a start, it motivates students. Although our data are largely anecdotal it seems that the drop out rate in Salters-Nuffield Advanced Biology is smaller than is typically the case in advanced level biology courses and that one reason for this is that students can see why they are studying what they are studying. For example, topic 2 includes some quite conventional material on transport across membranes and Mendelian 
inheritance. However, it does so in the context of cystic fibrosis and a scenario in which a couple at risk of cystic fibrosis are trying to decide whether or not to have a baby. Unsurprisingly, the average 16-19 year-olds finds this a relevant and engaging question that allows simple inheritance and the movement of water and other substances across membranes to be covered in a meaningful context.

But there is a second and somewhat deeper point that can be made and that is that the history of science suggests that much fundamental work in biology is context-driven. Today, governments and private companies (for example in the pharmaceutical industry) spend huge amounts of money on applied research. Often such applied research leads to fundamental scientific advances but it is a mistake to think that the path from fundamental science to technology is simple and unidirectional. Teaching through contexts may often be a more realistic way of modelling the way scientific knowledge is produced.

\section{Today's biology raises a wide range of ethical issues}

Few would deny that today's biology raises a wide range of ethical issues. One only has to think of in vitro fertilisation, therapeutic cloning, genetic engineering, global climate change, conservation, animal experimentation and end-of-life issues to appreciate that. But what precisely might be the aims of teaching ethics to biology students? Based on Davis (1999), at least four can be suggested (Reiss, 1999). 
First, such teaching might heighten the ethical sensitivity of participants. For example, students who have never thought about whether certain breeds of dogs should have their tails removed ('docked') or whether a fetus that is not capable of feeling anything can be said to have rights might be encouraged to think about such issues. Such thinking can result in students becoming more aware and thus more sensitive. It is not unusual, as a result, to find students saying 'I hadn't thought of that before'.

Secondly, such teaching might increase the ethical knowledge of students. The arguments in favour of this aim are much the same as the arguments in favour of teaching any knowledge - in part that such knowledge is intrinsically worth possessing, in part that possession of such knowledge has useful consequences. For example, appropriate teaching about the issue of rights might help students to distinguish between legal and moral rights, to understand something of the connections between rights and duties and to be able to identify fallacies in arguments for or against the notion of animal rights.

Thirdly, such teaching might improve the ethical judgement of students. As Davis, writing about students at university, puts it:

The course might, that is, try to increase the likelihood that students who apply what they know about ethics to a decision they recognize as ethical will get the right answer. All university courses teach judgment of one sort of another. Most find that discussing how to apply general principles helps students to apply those principles better; many also find that giving students practice in applying them helps too. Cases are an opportunity to exercise judgement. The 
student who has had to decide how to resolve an ethics case is better equipped to decide a case of that kind than one who has never thought about the subject.

(Davis, 1999, pp. 164-5)

Fourthly, and perhaps most ambitiously, such teaching of ethics might make students better people in the sense of making them more virtuous or otherwise more likely to implement normatively right choices. For example, a unit on ethics for biology students might lead the students to reflect more on the career possibilities open to them, leading them to be less pressured by the views of others. There is, within the field of moral education, a substantial literature both on ways of teaching people to 'be good' and on evaluating how efficacious such attempts are (e.g. Wilson, 1990; Carr, 1991; Noddings, 1992). Here it suffices to note that while care needs to be taken to distinguish between moral education and moral indoctrination, there is considerable evidence that moral education programmes can achieve intended and appropriate results (e.g. Straughan, 1988; Bebeau, Rest \& Narvaez, 1999).

\section{A deeper understanding of what it is to be human}

One of the unfortunate things about recent reforms to school biology curricula in England and Wales has been the increasing extent to which organisms other than humans are marginalised. However, what is just as sad is that what is generally taught about human biology in school biology lessons is actually a generalised mammalian anatomy and physiology (Tunnicliffe \& Reiss, 2001). In itself there is nothing wrong with pupils knowing how mammals digest, breathe, hear, excrete and so on. But these 
are not the things that make us truly human. To be human is to possess the most remarkable product of evolution in the world: the human brain with its capacity to enable us to think, reflect, talk, create and appreciate beauty, display both virtue and vice and so on.

Now, I don't expect 11-16 year-olds to be subjected in biology lessons to full-blown courses on linguistics, neurobiology, epistemology, aesthetics or moral philosophy. But I do think that school biology courses for this age range would be a sight more interesting and relevant if within them they found time to tackle such issues as:

- What do we mean by intelligence? Is there only one sort of intelligence or are there multiple intelligences?

- Are differences between males and females innate or cultural?

- To what extent is human behaviour the result of selfish genes? Can we be truly altruistic?

- Is life-long marriage natural? Are there right ways to behave sexually?

- Is there a biological basis to aggression? Can biology tell us anything about warfare?

- What is the best way to learn and why?

Biology teaching sometimes needs to result in more than understanding - it should develop the potential for action

The question as to the whole purpose of school science education has been widely debated in recent years in the science education community. Increasingly it has been 
agreed that school science education should serve the needs of the whole school population (e.g. Millar, 1996). For this reason, scientific literacy, however this term is understood, is seen as the prime aim of science teaching (see also Layton et al., 1993; Irwin \& Wynne, 1996; Hodson, 1998). Generally, scientific literacy is seen as being a vehicle to help tomorrow's adults to understand scientific issues (Gräber \& Bolte, 1997). In the West, for example, it might be hoped that a good school science curriculum that took scientific literacy seriously would help pupils to understand the uncertainties around genetically modified foods, global warming and the radiation from mobile 'phones.

My contention here is that while the scientific literacy movement has much to commend it, it still offers too narrow a vision of what science education might achieve. For example, science educators in general and biology educators in particular need to explore what a science curriculum might be like that took as its premise the notion that science education should aim for social justice. This is not to suggest that this should be the only aim of school science; rather, that it is an aim that has been very greatly underplayed. Biology educators can build on the work of a number of authors including Rodriguez (1998), Longbottom \& Butler (1999), Roth \& Désautels (2002) and Barton et al. (2003), all of whom have extended the debate about the aims of school science. Situating science education within a framework of social justice brings it alongside certain other components of the curriculum. For too long the science education debate has been conducted without reference to the wider aims of schooling (cf. Marples, 1999). 
How might school science lessons prepare people for social justice beyond the science classroom? Gaell Hildebrand (2001) has argued in favour of what she terms 'critical activism' in science education. She urges that there should be both participation in science (doing science) and participation in debates about science (challenging science). I agree (Reiss, 2003). It is in doing science that pupils better understand how scientific knowledge is formed. It is in enabling pupils critically to discuss scientific issues that they not only become better able to understand the scope of science but more able to appreciate its potential for good and bad. While some may see this as an attack on science, I would argue that this attitude is akin to those who once held that religious education (in countries that permit it) should confine itself to 'the faith'.

For we live, surely, in an age when the power of science has never been more manifest. At the same time it is fortunate that, while many secondary students, and their parents before them, have unhappy memories of much of their school science education, both students and parents almost universally consider science education to be important. In the UK, for example, science is seen as a prestigious subject and valued for the understanding it offers (Osborne \& Collins, 2000; Reiss, 2000).

However, practical activities can no longer be confined to 'pure', 'safe' and 'confined' activities. These are increasingly rejected by students, validly, as boring and irrelevant. Instead, we need a teacher education that helps student undertake a range of activities that can enable them to develop criticality and the potential for action. For example, in studying the topic of conservation, one could imagine students 
actually doing something positive for conservation. Depending on their age they might do one or more of the following:

- Carry out a survey on the extent of litter at various distances from fish shops, newsagents, other retail outlets and schools.

- Calculate food miles and press their school canteen to provide more local foods.

- Construct and maintain a wildlife area in their school grounds.

- Lobby politicians over a conservation issue.

- Make a short video clip on a local conservation issue and place it on the school web-site.

- Make a short audio clip about a local conservation issue and send it to a local radio station.

For such teaching to avoid being partial, teachers would need to encourage their students to debate the pros and cons of such actions and would need to avoid pressurising them to engage in such actions. Beginning science (including biology) teachers themselves need support in teaching about controversial issues.

\section{References}

Barton, A. C., with Ermer, J. L., Burkett, T. A., \& Osborne, M. D. (2003). Teaching science for social justice. New York: Teachers College Press.

Bebeau, M. J., Rest, J. R., \& Narvaez, D. (1999). Beyond the promise: a perspective on research in moral education. Educational Researcher, 28(4), 18-26. 
Carr, D. (1991). Educating the virtues: An essay on the philosophical psychology of moral development and education. London: Routledge.

Chalmers, A. F. (1999). What is this thing called science?, $3^{\text {rd }}$ edn. Buckingham: Open University Press.

Davis, M. (1999). Ethics and the university. London: Routledge.

Gräber, W., \& Bolte, C. (Eds.) (1997). Scientific literacy: an international symposium IPN 154. Kiel: Institut für die Pädagogik der Naturwissenschaften an der Universitatät Kiel.

Hildebrand, G. M. (2001). Con/testing learning models. Conference paper presented at the Annual Meeting of the National Association for Research in Science Teaching, St Louis, 25-28 March.

Hodson, D. (1998). Teaching and learning science: Towards a personalized approach. Buckingham: Open University Press.

Irwin, A., \& Wynne, B. (Eds.) (1996). Misunderstanding science? The public reconstruction of science and technology. Cambridge: Cambridge University Press.

Kuhn, T. S. (1970). The structure of scientific revolutions, $2^{\text {nd }}$ edn. Chicago: University of Chicago Press.

Lakatos, I. (1978). The methodology of scientific research programmes. Cambridge: Cambridge University Press.

Layton, D., Jenkins, E., Macgill, S., \& Davey, A. (1993). Inarticulate science? Perspectives on the public understanding of science and some implications for science education. Driffield: Studies in Education.

Longbottom, J. E., \& Butler, P. H. (1999) Why teach science? Setting rational goals for science education, Science Education, 83, 473-492. 
Marples, R. (Ed.) (1999). The aims of education. London: Routledge.

Merton, R, K (1973). The sociology of science: Theoretical and empirical investigations. Chicago: University of Chicago Press.

Millar, R. (1996). Towards a science curriculum for public understanding. School Science Review, 77(280), 7-18.

Noddings, N. (1992). The challenge to schools: An alternative approach to education. New York: Teachers College Press.

Osborne, J., Simon, S., \& Collins, S. (2003). Attitudes towards science: a review of the literature and its implications. International Journal of Science Education, 25, 1049-1079.

Osborne, J., \& Collins, S. (2000). Pupils' \& parents' views of the school science curriculum: A study funded by the Wellcome Trust. London: King's College London.

Popper, K. R. (1934/1972). The logic of scientific discovery. London: Hutchinson.

Reiss, M. J. (1999). Teaching ethics in science. Studies in Science Education, 34, 115140.

Reiss, M. J. (2000). Understanding science lessons: Five years of science teaching. Buckingham: Open University Press.

Reiss, M. J. (2003). Science education for social justice. In Vincent, C. (Ed.), Social justice, education and identity (pp. 153-165). London: RoutledgeFalmer.

Reiss, M. (2005). The nature of science. In Frost, J., \& Turner, T. (Eds.), Learning to teach science in the secondary school: A companion to school experience (pp. 44-53). London: RoutledgeFalmer.

Reiss, M. J. (in press). Developing a new biology course for 16-19 year-olds. Journal of Science Education. 
Rodriguez, A. J. (1998). What is (should be) researcher's role in terms of agency? A question for the 21st century. Journal of Research in Science Teaching, 35, 963965.

Roth, W.-M., \& Désautels, J. (Eds.) (2002). Science education as/for socio-political action. New York: Peter Lang.

Straughan, R. (1988). Can we teach children to be good? Basic issues in moral, personal and social education, 2nd edn. Milton Keynes: Open University Press.

Reiss, M. J., \& Tunnicliffe, S.D. (2001). What sorts of worlds do we live in nowadays? Teaching biology in a post-modern age. Journal of Biological Education, 35, 125-129.

Wilson, J. (1990). A new introduction to moral education. London: Cassell. 